\title{
Anti-platelet aggregation of mixtures of betulinic oleanolic and maslinic acids and derivatives from medicinal plants
}

\author{
Foluso O Osunsanmi ${ }^{1 *}$, Babatunji E Oyinloye ${ }^{1,2}$, Rebamang A Mosa ${ }^{1}$, Monisola \\ I lkhile ${ }^{3}$, J Catherine $\mathrm{Ngila}^{3}$, Francis O Shode ${ }^{4}, \mathrm{M} \mathrm{Singh}^{5}$ and Andy R Opoku ${ }^{1}$ \\ ${ }^{1}$ Department of Biochemistry and Microbiology, University of Zululand, Private Bag X1001,KwaDlangezwa 3886, South Africa, \\ ${ }^{2}$ Department of Biochemistry, College of Sciences, Afe Babalola University, PMB 5454, Ado-Ekiti 360001, Nigeria, ${ }^{3}$ Department \\ of Applied Chemistry, University of Johannesburg, Doornfontein Campus, PO Box 17011, Doornfontein 2028, Johannesburg, \\ ${ }^{4}$ Department of Chemistry, Cape Peninsula University of Technology, Bellville Campus, PO Box 1906, Bellville 7535, ${ }^{5}$ Discipline \\ of Biochemistry, University of Kwa-Zulu Natal, Durban 4000, South Africa
}

*For correspondence: Email: alafin21@yahoo.com; Tel: +27744919604, +27791565341

\begin{abstract}
Purpose: To evaluate the antiplatelet aggregation and cytotoxic potential of betulinic acid (BA), oleanolic acid (OA), maslinic acid (MA) and their derivatives (3- $\beta$-acetyloleanolic acid (OAA) and $3-\beta$ acetylbeutulinic (BAA) from medicinal plants.

Methods: The compounds were characterized by nuclear magnetic resonance (NMR, both carbon 13 and hydrogen 1) (NMR), infra-red (FTIR) and mass spectroscopy (MS). The platelet aggregation inhibitory activities of the compounds $(1,3,5$ and $10 \mathrm{mg} / \mathrm{ml})$ were investigated separately on adenosine diphosphate $(A D P)$ and thrombin-induced rat platelet aggregation. Cytotoxicity studies were carried out on human embryonic kidney (HEK293) and hepatocellular carcinoma (HEPG2) cell lines using 3, 4, 5dimethylthiazol-2-yl)-2-5-diphenyltetrazoliumbromide assay.

Results: The compounds significantly $(p<0.05)$ inhibited platelet aggregation in a dose-dependent manner on thrombin and ADP agonist. BAAVOAA showed the highest activity on both agonists with $I C_{50}$ of 2.86 and $3.05 \mathrm{mg} / \mathrm{mL}$ respectively. BAA/OAA also showed better antiplatelet activity than aspirin (IC $\mathrm{C}_{50}$ of 6.45 and $7.36 \mathrm{mg} / \mathrm{mL}$, respectively). In addition the compound (BA/OA, BAA/OAA and MA/OA) exhibited low cytotoxic effect on both HEK293 cells (IC $50: 724.43,269.08$ and $407.89 \mathrm{mg} / \mathrm{mL}$ respectively) and HEPG2 (IC $50: 585.38,499.78$ and $499.78 \mathrm{mg} / \mathrm{mL}$, respectively).

Conclusion: BAA/OAA demonstrate the best antiplatelet potential and low cytotoxicity of in all the tests, and therefore can serve as safer antiplatelet agents.
\end{abstract}

Keywords: Platelet aggregation, Agonist, Aspirin, Betulinic Acid, Oleanolic Acid, Maslinic Acid, Cytotoxicity

Tropical Journal of Pharmaceutical Research is indexed by Science Citation Index (SciSearch), Scopus, International Pharmaceutical Abstract, Chemical Abstracts, Embase, Index Copernicus, EBSCO, African Index Medicus, JournalSeek, Journal Citation Reports/Science Edition, Directory of Open Access Journals (DOAJ), African Journal Online, Bioline International, Open-J-Gate and Pharmacy Abstracts

\section{INTRODUCTION}

Abnormal platelet aggregation is instrumental to the pathogenesis of thromboembolic events such as stroke, deep venous thrombosis, heart attack and pulmonary embolism [1]. Endogenous agonists such as collagen, epinephrine, ADP, and thrombin induce platelet aggregation. These agonists trigger phospholipase (PLC) family that cleave phosphatidylinositol-4, 5- bisphoshate into inositol 1, 4, 5 bisphosphate (IP3) and diacylyglycerol (DG). The IP3 and DG initiate calcium influx and activation of protein kinase respectively [1]. Despite availability the antiplatelet drugs, mortality rate associated with cardiovascular diseases is on the increase. Most 
of the current used anti-platelet drugs are with undesirable side effects [2]. Therefore, there is need to search for alternative treatment from natural origin.

Melaleuca braceteata belongs to Myrtaceae family and it is indigenous in Australia, commonly called golden bottle brush, punk and white cloud tree [3]. The essential oil from $M$. braceteata has been reported to possess antibacterial, antifungal, antiseptic, insecticide and eliminate genital wart [4].

Syzygium aromaticum (clove) belongs to Myrtaceae family and it is indigenous to Indonesia [5]. S. aromaticum is commonly used as nutritional spice [5]. S. aromaticum has been also demonstrated to possess antimicrobial, antiseptic, aphrodisiac, anti-emetic, antiinflammatory and carminative properties $[5,6]$.

Triterpenes possess wide spectrum of biological activities such as anti-inflammatory, anti-HIV, antimutagenic antimicrobial, antitumor and anticancer [7]. In this present study, the antiplatelet aggregation activity and cytotoxic effect of the mixture of BA/OA, BAA/OAA as well as MA/OA were investigated.

\section{EXPERIMENTAL}

\section{Reagents}

Unless otherwise stated, all reagents were purchased from Sigma-Aldrich and were of analytical grade.

\section{Plant materials}

Fresh leaves of Melaleuca braceteata var. revolution gold were collected in March, 2014 from trees growing within the KwaDlangezwa campus of University of Zululand, South Africa. The plant was authenticated by Dr NR Ntuli of Department of Botany, University of Zululand. A voucher specimen (voucher number FO4) was deposited at the University Herbarium.

Syzygium aromaticum (cloves) was purchased from spices market in Durban, South Africa and were authenticated by Mr. Pawn Porum of the Department of Botany, University of KwaZuluNatal, Westville campus with the voucher specimen (VN/004) which was deposited at the University of KwaZulu-Natal Herbarium.

\section{Extraction and isolation of BA/OA from Melaleuca bracetata var. revolution gold}

The method of Habila et al [8] was adopted with slight modification. Fresh leaves of $M$. braceteata
(600 g) were dehumidified and extracted by maceration in ethyl acetate at room temperature ( $5 \mathrm{~L} \times 3)$ for $72 \mathrm{~h}$. The filtrate was concentrated with rotatory evaporator $\left(40{ }^{\circ} \mathrm{C}\right)$ to yield $0.8 \%$ of the crude extract. The crude extract was then defatted with n-hexane. A portion of the crude extract $(6 \mathrm{~g})$ was subjected to silica gel (60-120 mesh) column chromatography (20 x $5.5 \mathrm{~mm})$ using a gradient of $\mathrm{n}$-hexane and ethylacetate (8:2 to 7:3) as the solvent system. A total of 77 fractions of eluates $(20 \mathrm{ml}$ each) were collected and analyzed with thin layer chromatography. Fractions with the desired compounds monitored with TLC were combined and concentrated by rotatory evaporator. This was then recrystallized with methanol to form a white powder. Attempts to further separate the mixture of BA/OA were unsuccessful.

\section{Synthesis of BAA/OAA from BA/OA}

The method described by Andrine et al [9] was adopted. The mixture of BA/OA $(2 \mathrm{~g})$ isolated from $M$. braceteata var. revolution gold was dissolved in a solution containing a mixture of pyridine $(10 \mathrm{ml})$ and acetic acid anhydride (12 $\mathrm{ml})$. This was refluxed for $8 \mathrm{~h}$ until a complete solution result. The reaction was terminated by the addition of distilled water $(25 \mathrm{ml})$ and stirring for another $45 \mathrm{~min}$. The synthesized compounds were rinsed with $12 \% \mathrm{HCl}$ to remove excess pyridine and dehumidified at room temperature. The compounds were further purified by silica gel (60 x 120 mesh) column chromatography (20 x $5.5 \mathrm{~mm}$ ), and eluted with a gradient of n-hexane and ethylacetate (8:2 to 7:3). Forty seven fractions of eluates $(20 \mathrm{ml}$, each) was collected and analysed by TLC. Fractions with desired compounds were combined and concentrated using rotatory evaporator at $40{ }^{\circ} \mathrm{C}$. The mixture of BAA/OAA was recrystallized with methanol and air-dried to give a white powder.

\section{Extraction and isolation of MAVA from $S$. aromaticum (cloves)}

The method of Ibrahim et al [10] was used with slight modification. Buds of $S$. aromaticum (400 g) were milled by an industrial blender. The milled samples were extracted with dichloromethane $(2 \mathrm{~L} \times 3)$ for $24 \mathrm{~h}$ on a lab com shaker (36 rpm, $37^{\circ} \mathrm{C}$ ) and filtered. The filtrate was concentrated with rotatory evaporator (40 ${ }^{\circ} \mathrm{C}$ ) to yield $2.0 \%$ of the initial weight of plant samples. The crude extract was de-fatted with nhexane and a portion ( $7 \mathrm{~g})$ was subjected to silica gel $(60-120 \mathrm{~mm})$ column chromatography $(20 \times 5.5 \mathrm{~mm})$ using $\mathrm{n}$-hexane and ethyl acetate solvent system ranging from $9: 1$ to $8: 2$. Total fractions of (58) eluates $(30 \mathrm{ml}$, each) were 
collected and analyzed with TLC. Fractions containing desired compounds were combined and concentrated using rotatory evaporator (40 ${ }^{\circ} \mathrm{C}$ ) to obtain white amorphous solid.

\section{Experimental animals}

Adult Sprague Dawley rats $(220$ - 250 g) of either sex were used. The animals were maintained under light condition (12/12 $h$ light/dark), humidity (55 \%), constant temperature $\left(22 \pm 2{ }^{\circ} \mathrm{C}\right)$ and had access to pellet feeds and safe drinking water. The experiments were approved (UZREC 171110-030 PGD 2014/53) by Research Animal Ethic Committee (RAEC) of the University of Zululand and were conducted based on the guideline for the use of laboratory animals [11].

\section{Plasma-rich platelet (PRP)}

Plasma-rich platelet (PRP) was prepared according to the method described by Mosa et al [12]. The animals were sacrificed by cervical dislocation and blood was collected from punctured heart with surgical needle $(5 \mathrm{ml})$.

The blood was transferred into a $15 \mathrm{ml}$ test tube containing anticoagulant (acid-dextrose, $85 \mathrm{mM}$ trisodium citrate, $83 \mathrm{mM}$ dextrose and $21 \mathrm{mM}$ citric acid). Plasma-rich platelet was obtained through series of centrifugation at $1200 \mathrm{rpm}$ for $15 \mathrm{~min}$ and $2200 \mathrm{rpm}$ for $3 \mathrm{~min}$ consecutively. The supernatant was further centrifuged at 3200 $\mathrm{rpm}$ for $15 \mathrm{~min}$. The residue was re-suspended in washing buffer $(5 \mathrm{ml}, \mathrm{pH}$ 6.5) while the supernatant was discarded and PRP were suspended in a small volume of suspending buffer $(0.4 \mathrm{mM} \mathrm{NaCl}, 15 \mathrm{mM}$ Tris- $\mathrm{HCl}, 5 \mathrm{mM}$ glucose, $\mathrm{pH}$ 7.4). The platelets were diluted with resuspending buffer $(1: 10)$ and were further mixed with calcium chloride $\left(0.4 \mathrm{ml}: 10 \mu \mathrm{Cacl}_{2}\right)$.

\section{Anti-platelet aggregation studies}

Anti-platelet aggregation activities of the compounds were determined by the method described by Ibrahim et al [13] with slight modification. Anti-platelet aggregation activity was investigated using ADP $(5 \mathrm{mM})$ and thrombin $(5 \mu / \mathrm{ml})$ as agonists. PRP $(100 \mu \mathrm{l})$ were pipetted into 96 wells plate and pre-incubated for 6 minutes at $40{ }^{\circ} \mathrm{C}$ with various concentration (1, 3,5 and $10 \mathrm{mg} / \mathrm{ml}$ ) of the compounds. Platelet aggregation was then induced with separate agonists $(20 \mu \mathrm{l})$. Anti-platelet aggregation activities of the compounds were measured by Bioteck plate and absorbance read at $415 \mathrm{~nm}$. Aspirin served as the positive control while DMSO $(1 \%)$ served as a negative control.
Antiplatelet aggregation activity was calculated by the formula. Inhibition $\%=$ Ao $-\mathrm{A} 1 /$ Ao $\times 100$ (where Ao is mean slope of control while A1 is mean slope of tested compound). The value of $I_{50}$ was calculated using statistical package origin 6.1.

\section{Cytotoxic assay}

The cytotoxicity of the compounds were determined by MTT (3, 4, 5-dimethylthiazol-2-yl)2-5-diphenyltetrazoliumbromide) assay described by Mosaman [14]. Human hepatocellular carcinoma (HepG2) and human embryonic kidney (HEK293) cells lines were used for this assay. The cell line in the tissue culture was grown in flasks $\left(25 \mathrm{~cm}^{2}\right)$ and trypsinized. This was then pipetted into 96 well plate at specific seeding densities and incubated for $24 \mathrm{~h}$ at 37 ${ }^{\circ} \mathrm{C}$. The medium was removed and replaced with fresh medium (MEM + Glutmax + antibiotics). The isolated compounds (50 - 350 $\mu \mathrm{l} / \mathrm{ml}$ ) were added in triplicate and incubated for $4 \mathrm{~h}$ at $37^{\circ} \mathrm{C}$. The medium was again removed and replaced with a complete medium (MEM + Glutmax + antibiotics + $10 \%$ fetal bovine serum). This was incubated for $48 \mathrm{~h}$ at $37{ }^{\circ} \mathrm{C}$ for MTT assay. The compounds' cytotoxic were evaluated by regression analysis using QED statistics program and $\mathrm{IC}_{50}$ values from the linear equation was used to calculate cells mortality $(50 \%)$.

\section{Statistical analysis}

The experiments were carried out in triplicate and data expressed as mean \pm standard deviation (SD). One-way analysis of variance (ANOVA) and post-hoc Dunnett's test were used to analyze the results using Graphpad prism software (version 5.03). Statistical significance was set at $p<0.05$.

\section{RESULTS}

\section{Compound identification}

\section{Sample 1 (BA/OA)}

BA/OA (Figure 1) white powder; mp 290-292 ${ }^{\circ} \mathrm{C}$; IR (KBr) $v_{\max } 3553,2990,1739,1453,1374$, 1239, $1087 \mathrm{~cm}^{-1} ; \mathrm{m} / \mathrm{z}(\mathrm{ESI}) 456\left(\mathrm{M}^{+}, \mathrm{BA} / \mathrm{OA}\right) ; \mathrm{\delta H}$ $\left(400 \mathrm{MHz}, \mathrm{CDCl}_{3}\right.$ and $\left.\mathrm{CH}_{3} \mathrm{OD}\right): 4.96(\mathrm{~s}, 1 \mathrm{H}), 4.44$ $(1 \mathrm{H}, \mathrm{s}), 4.43(1 \mathrm{H}, \mathrm{s}), 3.11,2.73,1.98,1.43,1.29$, $0.79-1.24(21 \mathrm{H}, \mathrm{m}) ;{ }^{\delta} \mathrm{C}\left(100 \mathrm{MHz}, \mathrm{CDCl}_{3}\right.$ and $\mathrm{CH}_{3} \mathrm{OD}$ ): see Table 1 .

\section{Sample 2 (BAA/OAA)}

BAA/OAA (Figure 2) white powder; mp 297-299 


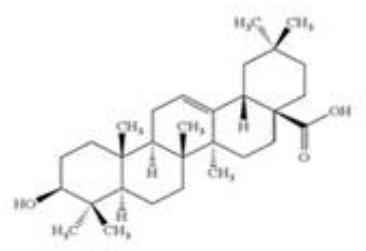

$\mathrm{OA}$
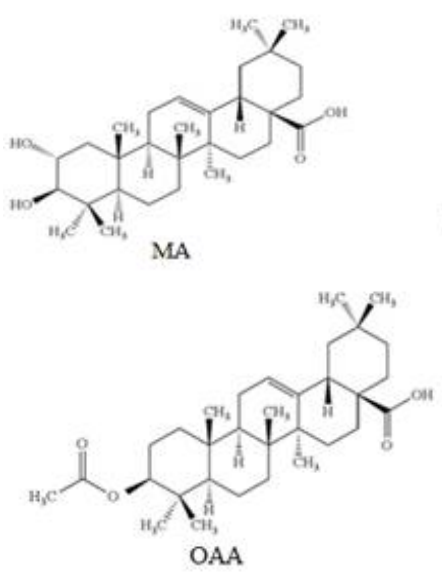

Figure 1: Structure of isolated compounds

${ }^{\circ} \mathrm{C}$; IR $(\mathrm{KBr}) \mathrm{v}_{\max } 2990,1739,1451,1373,1235$, $1045 \mathrm{~cm}^{-1} ; \mathrm{m} / \mathrm{z}$ (ESI) $498\left(\mathrm{M}^{+}, \mathrm{BAA}\right) \mathrm{m} / \mathrm{z}(\mathrm{ESI})$ $499\left(\mathrm{M}^{+}, \mathrm{OAA}\right) ; \delta \mathrm{H}\left(400 \mathrm{MHz} \mathrm{CDCl}_{3}\right): 5.18$ (s, $1 \mathrm{H}), 4.60(1 \mathrm{H}, \mathrm{s}), 4.47(1 \mathrm{H}, \mathrm{s}), 4.34(1 \mathrm{H}, \mathrm{s}), 2.88$, $2.11,1.95,1.93,1.81,1.57,0.72-1.49(\mathrm{~m}) ;{ }^{\delta} \mathrm{C}$ (100 $\mathrm{MHz} \mathrm{CDCl}_{3}$ ): see Table 1.

\section{Sample 3 (MA/OA)}

The compounds' identification has been reported in our previous research works [12].

The isolation of sample 1 and the formation of sample 2 were confirmed by ${ }^{1} \mathrm{H},{ }^{13} \mathrm{C}$ NMR and IR spectroscopy. The presence of hydroxyl groups in these compounds was indicated by the appearance of an absorption band around 3553 $\mathrm{cm}^{-1}$ in the IR Spectra. The $\mathrm{C}-\mathrm{H}$ stretching frequencies were observed around $2990 \mathrm{~cm}^{-1}$, also the bands that are characteristics of the presence of carboxylic acid in a molecule were observed around $1739 \mathrm{~cm}^{-1}$ [15]. The IH NMR spectra of samples 1 and 2 both revealed various peak corresponding to the methyl groups at around 0.72-1.49 ppm and terminal methylene protons at 4.34-5.18 ppm.

Further confirmation for the isolation of sample 1 and formation of sample 2 was provided by ${ }^{13} \mathrm{C}$ NMR spectroscopy. The ${ }^{13} \mathrm{C}$ NMR spectra of samples 1 and 2 showed that they were mixtures. This is as a result of the appearance of 60 carbons signals in ${ }^{13} \mathrm{C}$ NMR spectrum of sample 1 (30 each for $\mathrm{BA}$ and $\mathrm{OA}$ as assigned in Table 1) and 64 carbons signals in ${ }^{13} \mathrm{C}$ NMR spectrum of sample 2 (32 each for BAA and OAA as assigned in Table 1) which agree with the reported data for related compounds $[8,16]$. For sample 2 the appearances of four additional carbons in the ${ }^{13} \mathrm{C}$ spectrum (two each for BAA and OAA) assigned as C-31 and C-32 respectively (Table 1) further confirmed the formation of BAA/OAA. Further evidence for the isolation and formation of BA/OA and BAA/OAA was provided by the ESI-MS spectra which showed intense molecular ions corresponding to $\mathrm{M}^{+}$.

\section{Anti-platelet aggregation}

The compounds significantly $(p<0.05)$ inhibit platelet aggregation induced by ADP in a dosedependent manner (Figure 3a). BA/OA and BAA/OAA exhibited the highest anti-platelet aggregation activities. BAA/OAA mixture displayed optimal anti-platelet aggregation activity at $5 \mathrm{mg} / \mathrm{ml}$. BA/OA and BAA/OAA showed better $\mathrm{IC}_{50}$ value of $3.05 \mathrm{mg} / \mathrm{ml}$ and 3.25 $\mathrm{mg} / \mathrm{ml}$ respectively when compared with aspirin $\left(\mathrm{IC}_{50}\right.$ value of $\left.7.36 \mathrm{mg} / \mathrm{ml}\right)$ the positive control (Table 2). Similarly, the compounds dosedependent significantly inhibit platelets aggregation in thrombin induced platelet aggregation (Figure 3b). BAA/OAA possessed the highest anti-platelet aggregation activity.
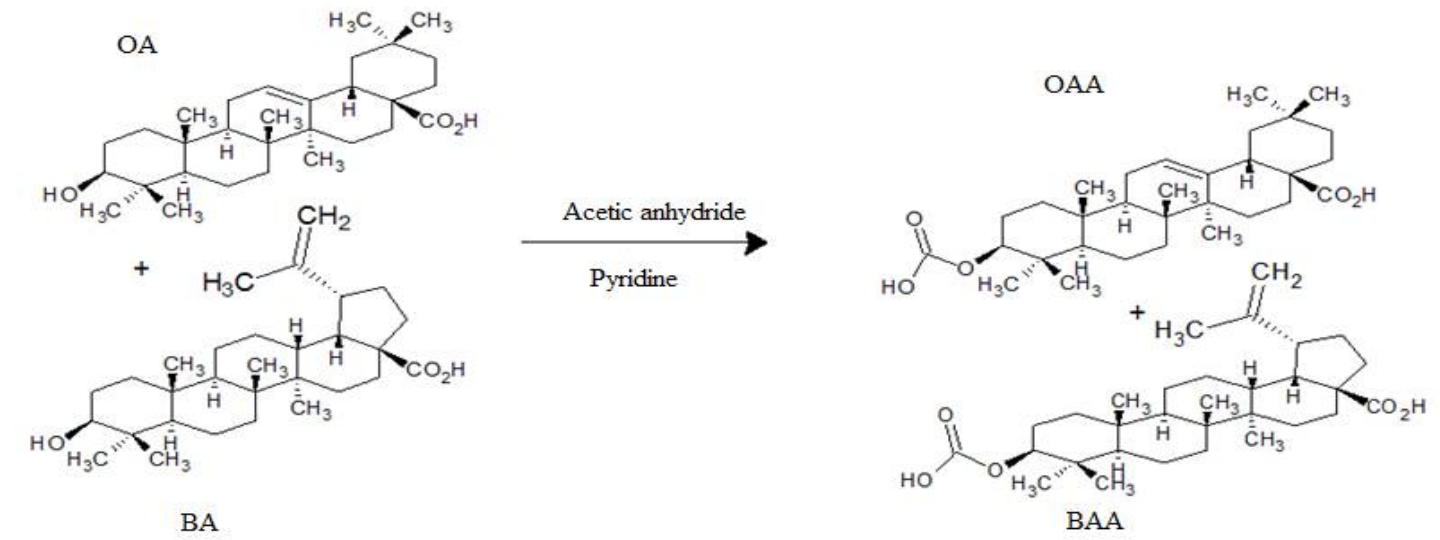

Figure 2: Schematic representation of the synthesis of BAAOAA from BA/OA 
Table 1: ${ }^{13} \mathrm{C}-\mathrm{NMR}(100 \mathrm{MHz})$ spectral data for sample 1 and 2

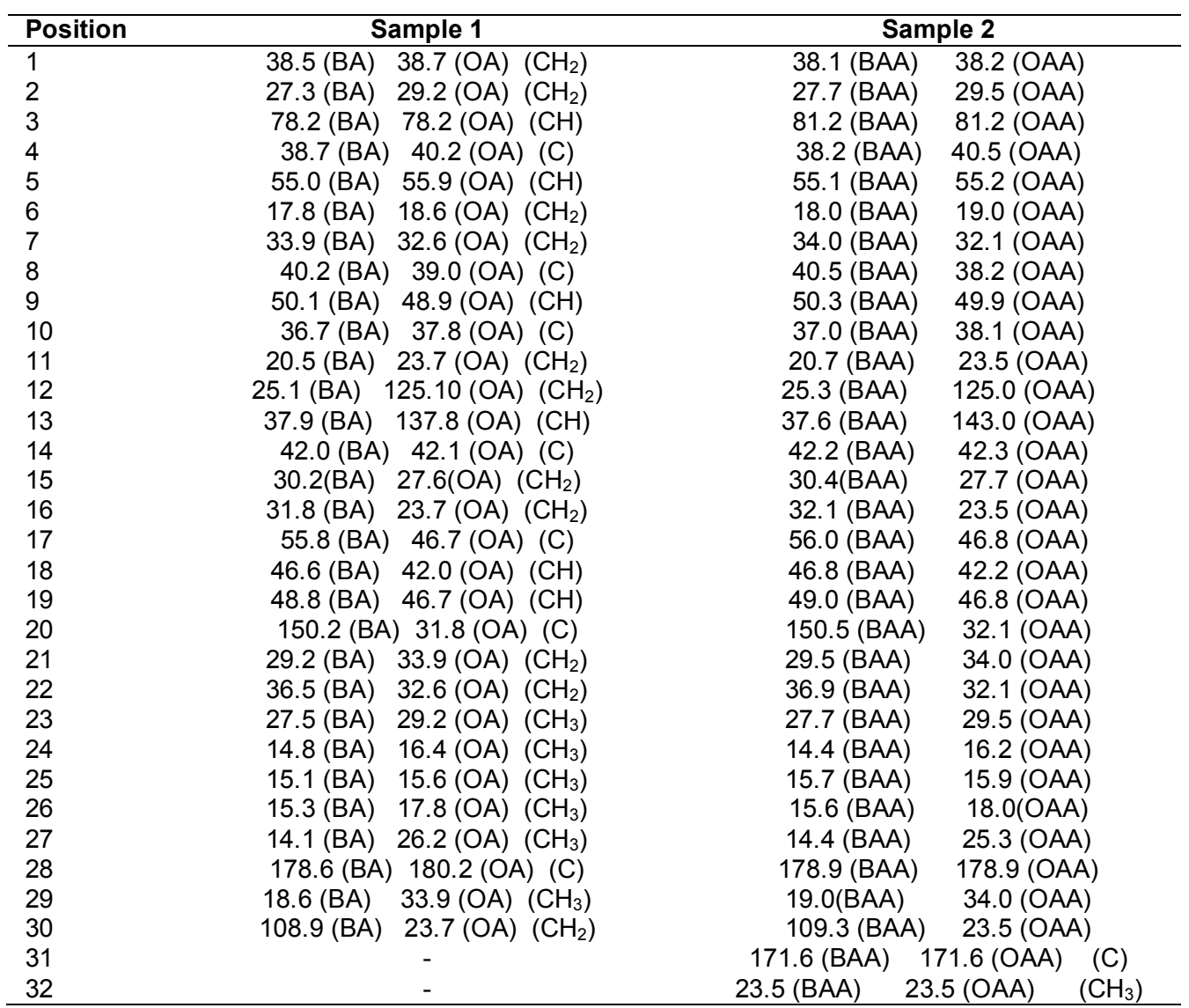

Data reported in ppm. BA, OA, BAA and OAA

Table 2: $\mathrm{IC}_{50}$ values of the compounds on platelet aggregation inhibition

\begin{tabular}{lcc}
\hline Compound & & $\mathbf{I C}_{\mathbf{5 0}}(\mathbf{m g} / \mathbf{m l})$ \\
\hline & Thrombin & ADP \\
BA/OA & 9.71 & 3.25 \\
BAA/OAA & 2.86 & 3.05 \\
MA/OA & 9.30 & 5.50 \\
Aspirin & 6.45 & 7.36 \\
\hline
\end{tabular}

BAA/OAA also showed better $I_{50}$ value of 2.86 $\mathrm{mg} / \mathrm{ml}$ than BA/OA and MA/OA mixture with $\mathrm{IC}_{50}$ value of $9.71 \mathrm{mg} / \mathrm{mL}, 9.30 \mathrm{mg} / \mathrm{ml}$ respectively. BAA/OAA $\left(\mathrm{IC}_{50}\right.$ value of $\left.2.86 \mathrm{mg} / \mathrm{ml}\right)$ was observed to possess twice the antiplatelet activity of aspirin $\left(\mathrm{IC}_{50}\right.$ of $\left.6.45 \mathrm{mg} / \mathrm{ml}\right)$.

\section{Cytotoxicity}

The result of cytotoxic assay revealed that all the compounds displayed poor cytotoxic effects on HEK293 and HEPG2 cells (Table 3). The compounds also showed better cytotoxic effects on HEPG2 than HEK293 cells, with BAA/OAA showing highest cytotoxic effect.
Table 3: $\mathrm{IC}_{50}(\mu \mathrm{g} / \mathrm{ml})$ of BA/OA, BAA/OAA and MA/OA acid on HEK293 and HEPG2 cells

\begin{tabular}{lcc}
\hline Compound & \multicolumn{2}{c}{ IC $_{50}(\mu \mathrm{g} / \mathrm{ml})$} \\
\hline & HEK 293 & HEPG2 \\
BA/OA & 724.43 & 585.38 \\
BAA/OAA & 499.78 & 269.08 \\
MA/OA & 499.78 & 407.89 \\
\hline
\end{tabular}

\section{DISCUSSION}

Platelet aggregation plays important role in thrombus formation [1]. Therefore, targeting abnormal platelet activation may be a promising approach to reduce cardiovascular mortality. Medicinal plants are currently the source of diverse bioactive compounds which are used for treatment of diseases. The multi-therapeutic properties of plant-derived triterpenes have made them the potential candidates for synthesis of new drugs. The present study revealed that the plant-derived triterpenes and derivatives possess anti-platelet aggregation activities regardless of the agonists. Anti-platelet aggregation activities of some triterpenes have previously been reported $[17,18]$. 
A

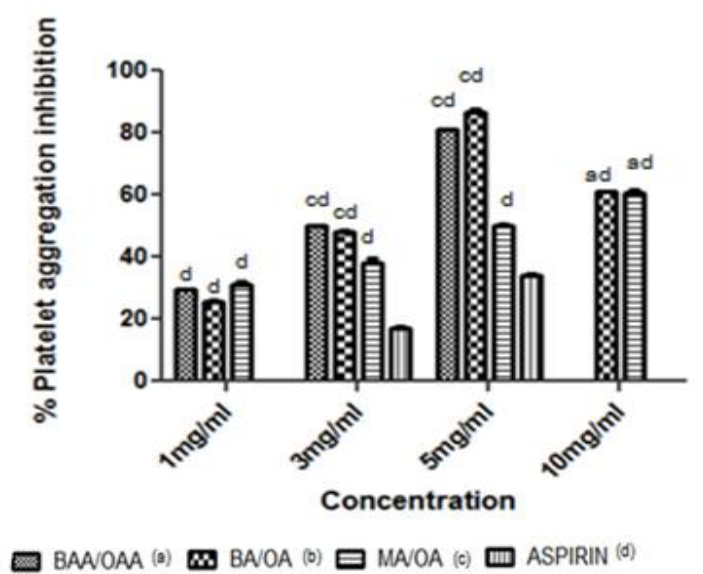

B

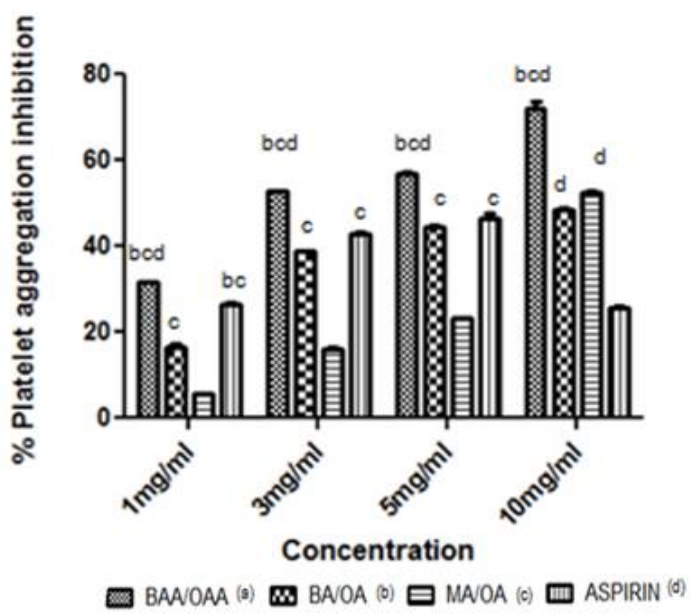

Figure 3: Percentage Inhibitory activity of (a) ADP induced by platelet aggregation. (b) Thrombin induced by platelet aggregation. Data expressed as mean \pm SD. Values of different letters in graph are significant $(p<0.05)$.

The anti-platelet aggregation activity of BA/OA mixture isolated from the leaves of Callisteum viminalis has also been reported, and further separation of BA/OA mixture using open column silica gel chromatography has been unsuccessful [13]. The highest antiplatelet aggregation activity of BAAIOAA mixture could be attributed to the modification of hydroxyl moiety at C3 position with acetyl group. Targeting of carbon positions 3 and 28 of compounds are the new pharmacophores to enhance biological activities [19]. It is worth noting that aspirin, a potent antithrombin agent has acetyl moiety as its major functional group [20]. To the best of our knowledge, this is the first time the BAA/OAA mixture was investigated as antiplatelet aggregation agent.

In the search for potent and clinically safe antiplatelet drugs, there is need to evaluate their toxicities and safety margins [10]. The American National Cancer Institute guidelines consider compounds with $\mathrm{IC}_{50}<30 \mu \mathrm{g} / \mathrm{ml}$ as cytotoxic [21]. The present study revealed that the compounds possessed weak cytotoxic properties in Table 3 on both normal cells (HEK293) and cancerous cell (HEPG2). This is contrary to previous reports of some triterpenes with strong cytotoxic effects [22,23]. Despite the weak cytotoxic effect of the compounds, they displayed better cytotoxic effects on HEPG2 than HEK293. This implies that the compounds could inhibit proliferation of cancer cell. Betulinic acid has previously been reported to selectively inhibit tumour cells [24]. Betulinic acid and derivatives isolated from Melaleuca cajuput have also been reported to selectively inhibit myeloid leukemia (HL-60) cell line [25].

\section{CONCLUSION}

This study reveals that the test compounds possess antiplatelet potential regardless of the agonists. Structural modifications of the compounds further enhances their activities, but reduced cytotoxic effects on normal cell line. Therefore, these compounds can serve as candidates for safer antiplatelet agents. However, there is need to ascertain the mechanisms of action of the compounds in further studies.

\section{DECLARATIONS}

\section{Acknowledgement}

The authors thank the University of Zululand Research Committee for her financial support.

\section{Conflict of Interest}

No conflict of interest associated with this work.

\section{Contribution of Authors}

The authors declare that this work was done by the authors named in this article and all liabilities pertaining to claims relating to the content of this article will be borne by them.

\section{REFERENCES}

1. Dickneite G, Seiffe D, Diehl KH, Rogers M, Czech J. Pharmacological characterization on a new 4amidinophenyl-alanine thrombin-inhibitor (CRC220). Thromb Res 1995; 77: 357-368. 
2. Armani S, Harnafi H, Gadi D, Mekhfi H, Legssyer A, Aziz M, Martin-Nizard F, Bosca L. Vaso-relaxant and antiplatelet aggregation effects of aqueous Ocimum basilicum extracts. J Ethnopharmacol 2009; 125: 157162.

3. Craven LA and Lepschi BJ. Enumeration of the species and infraspecific taxa of Melaleuca (Myrtaceae) occurring in Australia and Tasmania. Austral Syst Bot 1999; 12: 863-867.

4. Oliva B, Piccirilli E, Ceddia T, Ponteri E, Aureli P, Ferrini AM. "Antimycotic activity of Melaleuca alternifolia essential oil and its major components". Lett Appl Microbiol 2003; 37(2): 185-187.

5. Debjit BKP, Sampath K, Akhilesh Y, Shweta S, Shravan $P$, Amit SD. Recent Trends in Indian Traditional Herbs Syzygium aromaticum and its Health Benefits. I Pharmacogn Phytochem 2012; 1(1): 13-22.

6. Jirovetz L, Buchbauer G. Chemical Composition and Antioxidant Properties of Clove Leaf Essential Oils. J Agric Food Chem 2006; 54: 6303-6307.

7. Qian K, Nakagawa-Goto K, Yu D, Morris-Natschke LM, Nitz. TJ, Kilgore N, Allaway GP, Lee KH. Anti-AIDS agents 73: Structure-activity relationship study and asymmetric synthesis of 3-Omonomethylsuccinylbetulinic acid derivatives. Bioorg Med Chem Lett 2007; 17(23): 6553-6557.

8. Habila AJ, Habila JD, Shode FO, Opoku AR, Atawodi SE, Umar IA. Inhibitory effect of betulinic acid and $3 \beta$ acetoxybetulinic acid on rat platelet aggregation. Afr $\mathrm{J}$ Pharm Pharmacol 2013; 7(43): 2881-2886.

9. Adrine MI, Gloria NS, Laura NC, Miriam SM, Myna N, Pascal SG, Célia RS. Simone, CB. Synthesis and Antiplasmodial Activity of Betulinic Acid and Ursolic Acid Analogues. Molecules 2012; 17(10): 12003-12014.

10. Ibrahim G, Abdurahman EM, Ibrahim H, Ibrahim NDG and Yaro $\mathrm{AH}$. Toxicity and anti-inflammatory activity of Vernonia amygdalina Del. (Asteraceae) ethanol leaf extract. Chem Class J 2007; 4: 47-50.

11. National Institute of Health, USA. Public health service policy on human care and use of laboratory animals, 2002.

12. Mosa RA, Oyedeji OA, Shode FO, Singh M, Opoku AR. Triterpenes from the stem bark of Protorhus longifolia exhibit anti-platelet aggregation activity. Afr J Pharm Pharmacol 2011; 5(24): 2698-2714.

13. Ibrahim T, Babalola R, Shode OS, Adelakun EA, Opoku $A R$ and Rebamang AM. Platelet-Aggregation Inhibitory activity of oleanolic acid, ursolic acid, betulinic acid and maslinic acid. J Pharmacog Phytochem 2013; 1(6): 1317

14. Mosaman T. Rapid colorimetric assay for cellular growth and survival: Application to proliferation and cytotoxicity assays. J Immunol Methods 1983; 65(1-2): 55-63.

15. Mahato SB, Kundu AP. $13 C$ NMR Spectra of pentacyclic triterpentenoids- $A$ compilation and Salient Features. Phytochem 1994; 37(6): 1517-1575.

16. Seebacher $W$, Simic $N$, Weis $R$, Saf $R$. and Kunert $O$. Complete assignments of $1 \mathrm{H}$ and $13 \mathrm{C}$ NMR resonances of oleanolic acid, 18a-oleanolic acid, ursolic acid and 11oxo derivatives. Magn Reson Chem 2003; 41: 636-638.

17. Habila JD, Shode FO, Opoku AR. Triterpenoids from Eucalyptus grandis Hill ex Maiden inhibits platelet aggregation. Afr J Microbiol Res 2011; 5(26): 4646- 4 651.

18. Tzakos AG, Kontogianni VG, Tsoumani M, Kyriakou E, Hwa J, Rodrigues FA, Tselepis AD. Exploration of the antiplatelet activity profile of betulinic acid on human platelets. J Agric Food Chem 2012; 60(28): 6977-83.

19. Ban HS, Minegishi H, Shimizuk K, Maruyama M, Yasui Y, Nakamura H. Discovery of carbrances as inducers of $20 S$ proteasome activity. Chem. Med Chem 2010; 5:1236-12

20. Undas, A, Brummei-Ziedins KE, Mann KG. Antithrombotic properties of aspirin and resistance to aspirin: beyond strictly antiplatelet action. Blood 2007; 15: 109 (6): 2285-2292

21. Suffness M, Pezzuto JM. Assays related to cancer drug discovery. In Methods in Plant Biochemistry: Assays for Bioactivity; Hostettman, K., Ed. Academic Press: London, UK 1990; pp 1-7.

22. Lee HS, Kim SD, Lee WM, Endale M, Kamruzzaman SM, Oh WJ, Cho JY, Kim SK, Cho HJ, Park HJ, Rhee MH. A noble function of elevated CAMP-induced VASP, and decreased ERK2/JNK1 phosphorylations. Eur J Pharmacol 2010; 627(1-3): 85-91.

23. Peteros NP and Uy MM. Antioxidant and cytotoxic activities and phytochemical screening of four Philippine medicinal plants. J Med Plants Res 2010; 4(5): 407-414.

24. Pisha E, Chai H., Lee, I.S., et al., Discovery of betulinic acid as a selective inhibitor of human melanoma that functions by induction of apoptosis. Nat Med 1995; 1(10): 1046- 51.

25. Faujan NH, Alitheen NB, Yeap SK, Ali AM, Muhajir AH, Ahmad FBH. Cytotoxic effect of betulinic acid and betulinic acid acetate isolated from Melaleuca cajuput on human myeloid leukemia (HL-60) cell line. Afr $J$ Biotechnol 2010; 9(38): 6387-6396. 